3. ミトユンドリヤの啌胞化， fibrile の增加等は… 般的退化変性の現象と見ているのか，それ之も特別の見 解をもつか.

\section{応 答}

英俊（口空組織）

1.次のような関係にあります。

I型 $\rightarrow$ 味細胞（暗調練胞）

几型 $\rightarrow$ 支持細胞 (明調細胞)

III型 電顕的に見出された〈Murray， Murray and

Fujimoto, 1969）新しいタイプの紏胞

$\mathrm{IV}$ 型 $\rightarrow$ 基底細胞

2. 従来汃ら，味笛の各細胞は基底細胞汃ら分化する とされ，前質問者にも答えたように，その動態は $\mathrm{H}^{3}$ thymidine によって追跡されています. しかしまだ， 味蕾の全細胞が基底細胞より分化するものかどうか疑問 が残されています。

3. 吾々の所見のみならず，他の実駼報告からも退化 変性の形態的特徴のようです.

\section{6. 歯周療法ならびに歯内療法の $2 ， 3$ の臨床例につい $\tau$}

\section{○山本博武・津覇 実・吉田光雄 (2 保存)}

1 症例，患者，S．K．14才，令，期間，S49.7.2 3〜49.9.21. 㟝断名, $\frac{7+1-7}{7+7} \mathrm{P}_{2}$ (思春期性), 治療方法, 歯石除去, 雨肉マッサージ, 雨肉切除, 病理組織標本の ヘマトキシリン・エオデン（H．E）染色やアザン染色 で粘膜の表面の角質層では核は殆んどなく，内縁より外 縁上皮部では重層扁平上皮は大きく乱れ，基底部では膠 原繊維束が認められ，内皮細胞の血管壁は肥厚してい る.

2 症例, 患者, H. K. 13才， 合，期間， S 49.11. 22〜50. 3. 14. 診断名, $\frac{3 \mid 3}{3} \mid \frac{3}{3} \mathrm{P}_{2}$, (思春期性) 治療方 法, 㧘石除去, 雨肉マッサージ, 雨肉切除, 病理組織標 本のH．E染色やアザン染色では 1 症例と大差は認めら れないが万能顕微鏡（アポフォト）の微分干渉装置 $(\mathrm{T}$ ) によれば粘膜上皮の重層啢平上皮や膠原繊維の部分で大 きく入乱が認められた。

3 症例，患者，Y.T. 20 才，早，期間，S49. 7 . 23〜 49. 7. 31. 診断名, II 遠心荬肉部の papilloma (乳嘴腪)，治療方法, papilloma の切除, 病理組織 標本では粘膜上皮は上皮細胞と結合組織繊維が譛められ papilloma 特有な球状の層がみられた。

4 症例, 患者は T. T. 58才，含，期間，S43. 5 .

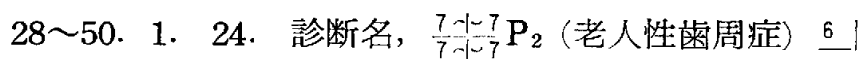

Pul，治燎方法は7ー4|ノイマン氏手術， 6 抜髄後に根管 充填， 7ー4整間店定を行なった。

5 聇例, 患者, $\mathrm{Y} . \mathrm{K}$. 38才, 肪，期間, S 49 . 4. $27 〜 50.5$. 23. 㟝断名， 12 composit レヂンによ る. Pul. $\longrightarrow$ Per. 治療方法は感染根管治療後に根管 充填を行ないガッタパーチヤポイントを抽出した症例X 線像を 2 月， 3 月，4月，5月に追跡調查を行なったも のである。

6 症例, 患者, A. M. 41才, 古, 期間, S50. 2 . 26〜50. 3. 20誩断名， 2 急性Per. (G. A.) 11 慢性 Per, 治療方法恃 2 部膿崲切開某霜科医院後 211 感染 根管治療後に根管充塡を行なったものである.
質 問
佐伯 栄一（[衛）

1. ポイントが根父孔よりかなり長く出ていますが， 意識して出されたのですか.

2. 䨤肉切除の際に菌坧顕示をされているように思え ましたが何か関係あるのか。

応 答

山本 博武（1 保存）

1. 根光後のガッタパーチャポイントの抽出は, 遇然 であり，臨床的に症例がなかったので観察を行なった。

2. カラーテスタ一の使用は除石，ブラッシング指導 後に時々使用しました。

\section{7. 犬の大腿骨頭に於ける分裂線の関節軟骨 と骨質表面 との関係に就て}

。鳥谷 潤・村上守良・中山種秋（解剖）

1. 研究目的

分裂線法を用いての研究報告は従来より数多くある が，いづれも関節軟骨の発育過程の報告のみで，関節軟 骨と骨質表面との関係は解明されてなく，従って犬の大 腿婴頭を用いて関節軟骨と骨質表面の分裂線とを比較検 討を試みたので，その結果の概要を報告する.

2. 研究材料ならびに方法

材料は実験用ビーグル犬生後 6.8．11力月． 1.2 3. 4.6 年の33頭の右側大腿骨を使用した。 そして通 法の如く関節軟骨とそれに被はれた骨質表面を穿刺し た. 生後 4 力月以下の幼弱犬では骨緻密質の発育がまだ 不完全で骨質表面と関節軟省の比較は出来なかったので 除外した。

\section{3. 所兒}

1) 生後 6 力月は不整裂線が散在し線系自体の不整化 がみられる。

2）8ケ月は 6 力月よりやや線系化を示す. 